\title{
Performance and economic analysis of finished lambs in feedlot
}

\section{Desempenho e análise econômica da terminação de cordeiros em confinamento}

\author{
Euclides Reuter de Oliveira ${ }^{1}$; Flávio Pinto Monção ${ }^{2 *}$; \\ Andréa Maria de Araújo Gabriel ${ }^{1}$; Felipe de Souza Santos Abreu; \\ Lais Valenzuela Moura ${ }^{3}$; Felipe de Almeida Nascimento ${ }^{4}$; \\ Vadim Milani de Souza Carbonari5; Thais Assad Galharte Figueiredo ${ }^{3}$
}

\begin{abstract}
This study aimed to evaluate animal performance and economic performance of feedlot crossbred lambs ( $1 / 2$ Santa Inês $+1 / 2$ Suffolk) fed different diets based on hay from Cynodon dactylon genotypes, through the use of financial measures considering only the period of feedlot, without relating it to the complete management cycle. A total of 30 intact crossbred Suffolk lambs, identified with earrings, with an average age of 90 days and an average body weight of $21.5 \mathrm{~kg}$ were used in this study. Diets were formulated using as treatments a standard concentrate and hay of the Cynodon dactylon genotypes Jiggs, Vaquero, Tifton 68, Coast-Cross, Tifton 85 and Russell in a 60:40 forage-to-concentrate ratio. The treatments were distributed in a randomized complete block design with five replicates. There were significant differences between diets in terms of total expenditure on food, and the highest values were obtained for the Jiggs genotype (BRL 48.96/animal). The animals fed diets based on Tifton 68 hay had a higher rate of return (2.16\%) and profitability (34.63\%) compared to the other diets. The use of diets based on Tifton 68 hay for feedlot lambs in the finishing phase brings higher economic returns compared to the remaining diets.
\end{abstract}

Key words: Cynodon, financial indicators, forage, sheep, intensive system

\section{Resumo}

Objetivou-se avaliar o desempenho zootécnico e econômico de cordeiros mestiços $(1 / 2$ Santa Inês + $1 / 2$ Sulfolk), em confinamento, recebendo diferentes dietas a base de feno de genótipos de Cynodon dactylon, através do uso de indicadores financeiros considerando o período de confinamento, sem relacioná-lo com o manejo de ciclo completo. Foram utilizados 30 cordeiros, machos, não castrados, mestiços Suffolk, identificados com brinco na orelha, com média de idade de 90 dias e peso corporal médio de $21,5 \mathrm{~kg}$. As dietas foram formuladas utilizando um concentrado padrão e feno dos seguintes genótipos de Cynodon dactylon: Jiggs, Vaquero, Tifton 68, Coast-Cross, Tifton 85 e Russel, em uma

\footnotetext{
${ }^{1}$ Profs., Universidade Federal da Grande Dourados, UFGD, Departamento de Ciências Agrárias, UFGD, Dourados, MS, Brasil. E-mail: euclidesoliveira@ufgd.edu.br; andreagabriel@ufgd.edu.br

2 Discente de Doutorado em Zootecnia, Universidade Estadual Paulista "Júlio de Mesquita Filho", UNESP, Campus Jaboticabal, Jaboticabal, SP, Bolsista da FAPESP. Brasil. E-mail: moncaomoncao@yahoo.com.br

${ }^{3}$ Discentes de Mestrado em Zootecnia, UFGD, Dourados, MS, Brasil. E-mail: valenzuelamoura@bol.com.br; thais_assad@ hotmail.com; felipessabreu@yahoo.com.br

${ }^{4}$ Discente de Mestrado em Zootecnia, Universidade Estadual Paulista “Júlio de Mesquita Filho", UNESP, Campus Jaboticabal, Jaboticabal, SP, Brasil. E-mail: phelipe_nascimento@hotmail.com

5 Discente de Agronomia, UFGD, Dourados, MS, Brasil. E-mail: vadimcarbonari@hotmail.com

* Author for correspondence
} 
relação volumoso concentrado de 60:40, constituindo os tratamentos, distribuídos em um delineamento em blocos casualizados com 5 repetições. Houve diferença significativa entre as dietas para as despesas totais com a alimentação, sendo os maiores valores para o Jiggs (BRL 48,96/animal). Os animais que receberam dietas a base de feno de Tifton 68 apresentaram maior taxa de retorno $(2,16 \%)$ e lucratividade $(34,63 \%)$ em relação às demais dietas. A utilização de dietas a base de feno de Tifton 68 para cordeiros em fase terminação, em confinamento, permite obter maior rentabilidade econômica em relação às demais dietas.

Palavras-chave: Cynodon, forragem, indicadores financeiros, ovinos, sistema intensivo

\section{Introduction}

The use of feedlots as a management strategy for the finishing of lambs has advantages and disadvantages when used as the sole technology or when added in the production system. Some of the advantages include the possibility of early slaughtering of the animals and obtaining homogeneous and better-quality carcasses, which is reflected in better prices paid by the consumer market and the guarantee of faster return on invested capital for the producer (PACHECO et al., 2014b).

However, feeding is one of the factors that contribute the most to the production costs by reducing the profit margins of farmers. Thus, the use of dietary strategies such as forage with higher nutritional value is an alternative to reduce production costs. Research results (OLIVEIRA et al., 2014a, b) have shown that some grasses of the genus Cynodon spp. have high yield and nutritional value, making it an important food alternative in the farming of lambs in intensive production systems. However, there are few studies focusing on the performance of feedlot lambs fed with genotypes of Cynodon spp., and such studies focus little on aspects related to economic viability, which hinders the application of the technical results from the producer's standpoint. It is known that the economic response is closely related to regional, national and/ or international variations in item costs, especially the prices of lambs and dietary ingredients, as shown in studies by Pacheco et al. (2014a) and Gerassev et al. (2013).

In addition, when using technical indicators of animal performance for achieving greater certainty when deciding whether to confine them, one must conduct an economic evaluation that takes the animals into consideration whenever possible (PACHECO et al., 2014a).

In this decision-making process, the estimate and joint evaluation of indicators of return and of investment risk result in more consistent data (SOUZA; CLEMENTE, 2009). The joint evaluation of economic indicators provides ease in the application of the methods, especially when using spreadsheets, and therefore ease in the interpretation of the estimates (PACHECO et al., 2014b), but these indicators are used less frequently in animal performance studies.

The study aimed to evaluate the animal and economic performances of feedlot crossbred lambs ( $1 / 2$ Santa Inês $+1 / 2$ Suffolk) fed different diets based on hay from Cynodon dactylon genotypes through the use of financial indicators, taking into account the feedlot period without relating it to the complete management cycle.

\section{Materials and Methods}

The study was conducted according to ethical standards and was approved by the ethics and biosafety committee of the University Center of Grande Dourados, under protocol number 223/07.

The experiment was conducted on the premises of the Animal Husbandry sector of the School of Agrarian Sciences (Faculdade de Ciências Agrárias FCA), at the Federal University of Grande Dourados (Universidade Federal de Grande Dourados UFGD), Dourados, state of Mato Grosso do Sul 
(MS), Brazil; latitude: $22^{\circ} 014^{\prime} \mathrm{S}$; longitude: $54^{\circ}$ 049' W; altitude: $450 \mathrm{~m}$. The climate of the region is Cwa (humid mesothermal) according to the Köppen (1948), with rainy summers and dry winters and an average annual temperature of $22^{\circ} \mathrm{C}$. The soil is classified as distroferric Red Latosol (Oxisol) (EMBRAPA, 1999). The study was conducted between December 2010 and October 2011.

The genotypes of the genus Cynodon studied were Jiggs, Vaquero, Tifton 68, Coast-cross, Tifton 85 and Russell. After the standardization cut, conducted at $5 \mathrm{~cm}$ above the ground level, $100 \mathrm{~kg}$ of Nitrogen $\mathrm{ha}^{-1}$ were broadcasted, and the forage was then made into hay at a regrowth age of 52 days. Cutting was conducted with the aid of a backpack brushcutter, leaving the forage exposed to the sun and wind in the field, where it was thoroughly mixed two to three times a day using rakes and forks. This method provided uniform dehydration until reaching the optimal point, with moisture content between 15 and 18\% (PUPO, 1979). Rectangular bales were made using a mechanical baler attached to a tractor. The entire hay-curing process took between 48 and 60 hours.

The bales were stored in covered warehouses on a wooden pallet, where they remained until use, and were ground into particles with a size between 1 and $2 \mathrm{~cm}$ with the aid of a shredder attached to the tractor. After hay production, the experimental phase began. A total of 30 Suffolk crossbred ( $1 / 2$ Santa Inês $+1 / 2$ Suffolk) intact male lambs, identified with earrings, with a mean age of 90 days and average body weight of $21.5 \mathrm{~kg}$, were used. The animals were randomly distributed in five randomized blocks, according to their initial body weight, with six treatments. Each treatment corresponded to a different hay genotype, i.e., Jiggs, Vaquero, Tifton 68, Coast-cross, Tifton 85 and Russell.

The animals were housed in a covered shed with a concrete floor lined with wood shavings and were provided with individual stalls $(1.20 \times 1.0 \mathrm{~m})$ containing individual feeders and drinkers.
Endoparasite control was strategically performed throughout the animals' stay in the feedlot by counting the number of eggs per gram of feces (EPG). Adaptation to the diets and facilities lasted for 14 days, and the experimental period lasted 84 days.

The feed contained $60 \%$ forage and $40 \%$ commercial concentrate (Table 1 ), on a dry matter basis. The variable between treatments was the hay genotypes.

Table 1. Chemical composition of the concentrate.

\begin{tabular}{lc}
\hline Ingredients & $\begin{array}{c}\text { Percentage in the } \\
\text { concentrate }(\%)\end{array}$ \\
\hline Soybean meal & 25.00 \\
Ground corn & 43.00 \\
Corn germ & 25.40 \\
Degummed oil & 2.00 \\
Dicalcium phosphate & 1.50 \\
Common salt & 1.75 \\
Calcitic limestone & 1.20 \\
Mineral premix & 0.15 \\
\hline
\end{tabular}

The feeding was performed at $7 \mathrm{am}$, when $60 \%$ of the daily amount was provided, with the remaining $40 \%$ being provided at $2 \mathrm{pm}$; water was available ad libitum. The daily intake was adjusted to allow a minimum of $15 \%$ of leftovers. The provided diets were formulated as recommended by the National Research Council (NRC, 2007). The proximate compositions of the different genotypes are shown in Table 2.

At the end of the experiment, the animals were subjected to solid fasting for 14 hours and then slaughtered. The slaughter was performed by stunning, followed by bleeding for five minutes by severing the carotid artery and jugular vein. The carcasses were cleaned, gutted and taken to a refrigeration chamber, where they remained hung by the tarsal-metatarsal joint, with 17-cm spacing between carcasses, for 24 hours at $5^{\circ} \mathrm{C}$. After cooling, they were weighed to obtain the cold carcass weight $(\mathrm{CCW})$. 
Table 2. Proximate compositions of the experimental diets.

\begin{tabular}{lcccccc}
\hline \multirow{2}{*}{ Nutrients } & \multicolumn{7}{c}{ DIETS } \\
\cline { 2 - 7 } & Coast-Cross & Jiggs & Vaquero & Tifton 85 & Tifton 68 & Russell \\
\hline DM & 92.88 & 92.65 & 92.86 & 92.43 & 92.56 & 92.58 \\
CP $^{1}$ & 10.36 & 12.63 & 10.98 & 11.91 & 12.3 & 11.47 \\
NDF $^{1}$ & 57.98 & 55.23 & 55.91 & 56.09 & 54.68 & 56.2 \\
$\mathrm{ADF}^{1}$ & 25.03 & 23.68 & 21.6 & 23.69 & 24.15 & 23.94 \\
Lig $^{1}$ & 4.65 & 3.97 & 4.08 & 4.34 & 4.37 & 4.43 \\
$\mathrm{TDN}^{1}$ & 69.4 & 70.46 & 72.08 & 70.46 & 70.09 & 70.26 \\
MM $^{1}$ & 5.92 & 6.36 & 6.07 & 5.78 & 6.21 & 6.12 \\
\hline
\end{tabular}

${ }^{1}$ On a DM basis; NDT calculated according to Patterson et al. (2000); DM: Dry matter; CP: Crude protein; NDF: Neutral detergent fiber; ADF: Acid detergent fiber; Lig: Lignin; TDN: Total digestible nutrients; MM: Mineral matter.

Data collection was conducted regarding the selling price of the animals and the cost of ingredients used in diets obtained through the historical price quotations of the Center for Advanced Studies in Applied Economics from ESALQ/USP (CENTRO DE ESTUDOS AVANÇADOS EM ECONOMIA APLICADA - CEPEA, 2014) and actual prices charged in the Dourados market, State of Mato
Grosso do Sul, Brazil. The prices of Cynodon hay were obtained by quantifying the processes that contributed to the final product, namely the quantification of diesel oil used until reaching the property, the daily wages of two workers, electricity, land depreciation, and hurdle rate - considering as a reference the income from savings ( $6 \%$ annually), with data outlined in Table 3.

Table 3. Cost of ingredients used in the experimental diets and annual dry matter production of the genotypes studied.

\begin{tabular}{lc}
\hline Ingredients & Price per kg \\
\hline Cynodon hay & BRL 0.50 \\
Corn grain & BRL 0.49 \\
Corn germ & BRL 0.39 \\
Soybean meal & BRL 0.55 \\
Calcitic limestone & BRL 0.20 \\
Dicalcium phosphate & BRL 0.20 \\
Degummed oil & BRL 0.87 \\
Mineral premix & BRL 1.52 \\
Genotypes & Annual average production (kg DM ha $\left.\mathbf{~}^{-1}\right)$ \\
Tifton 85 & 9.740 \\
Jiggs & 8.370 \\
Russell & 8.750 \\
Tifton 68 & 9.750 \\
Coast Cross & 9.768 \\
Vaquero & 8.670 \\
\hline
\end{tabular}

Sources: CEPEA (2014), Scott Consultoria (2014) and prepared by authors. 
The mean values for performance were subjected to analysis of variance; when significant according to the F-test, the means were compared using Tukey's test at a 5\% probability level using PROC MIXED from SAS (SAS institute, 2008).

For the economic and financial analysis, the methodology proposed by Pacheco et al. (2014a) and Gerassev et al. (2013) was used, incorporating financial measures, such as the total food cost, the acquisition cost of the ingredients making up the concentrate, and the total expenditure (TE), which enabled identification of whether the activity is profitable or not by multiplying the amount paid per kilogram of diet fed to the animals. The period in which the diet was provided ( 84 days) plus the cost of staff, energy, water, facilities and equipment, and medications were also included in the TE. The cost per $\mathrm{kg}$ of weight gain (ratio between the TE on food per diet and weight gain per diet in the finishing period in kilograms), gross revenue (GR), is given by multiplying the final live weight (FLW) with the value earned per $\mathrm{kg}$ sold. Net revenue (NR) was quantified by subtracting total expenditure on food during the finishing period from GR. The rate of return was calculated based on diet cost - the ratio between NR and TE on food - indicating the capital return for every monetary unit applied. Profitability was calculated considering the ratio of NR and GR, multiplied by 100 . This metric indicates the percentage of earnings obtained on sales. All calculations were performed on a fresh matter basis. The capital invested in buying the animals was BRL 3,000.00.

The economic analysis was performed taking into consideration the market prices of the dietary ingredients, the cost of animal acquisition and the values obtained from selling the lambs. Using the costs of each diet and the intake, the economic results provided by each diet were calculated.

\section{Results and Discussion}

There were significant differences between diets for dry matter intake (DMI), average daily weight gain (ADG), total weight gain (TWG) and feed conversion (FC) for feedlot lambs (Table 4). However, there was no difference between diets in terms of protein efficiency, with an average of 1.33 $\mathrm{kg}$ of weight gain $/ \mathrm{kg}$ crude protein.

Table 4. Performance characteristics of feedlot lambs fed different diets of hay from grasses of the genus Cynodon.

\begin{tabular}{lccccccc}
\hline \multirow{2}{*}{ Variables } & \multicolumn{7}{c}{ Diets } \\
\cline { 2 - 7 } & Coast & Jiggs & Vaquero & Tifton 85 & Tifton 68 & Russell & CV (\%) \\
\hline DMI & $0.888 \mathrm{ab}$ & $1.060 \mathrm{a}$ & $0.901 \mathrm{ab}$ & $0.874 \mathrm{ab}$ & $0.858 \mathrm{~b}$ & $0.876 \mathrm{ab}$ & 10.97 \\
ADG & $0.130 \mathrm{~b}$ & $0.180 \mathrm{a}$ & $0.152 \mathrm{ab}$ & $0.142 \mathrm{ab}$ & $0.149 \mathrm{ab}$ & $0.136 \mathrm{ab}$ & 15.45 \\
TWG & $10.98 \mathrm{~b}$ & $15.14 \mathrm{a}$ & $12.78 \mathrm{ab}$ & $11.96 \mathrm{ab}$ & $12.60 \mathrm{ab}$ & $11.43 \mathrm{ab}$ & 15.46 \\
FC & $6.87 \mathrm{a}$ & $5.92 \mathrm{~b}$ & $5.94 \mathrm{~b}$ & $6.15 \mathrm{ab}$ & $5.76 \mathrm{~b}$ & $6.51 \mathrm{ab}$ & 7.14 \\
PE $^{5}$ & 1.20 & 1.29 & 1.49 & 1.32 & 1.37 & 1.32 & 14.45 \\
\hline
\end{tabular}

DMI: Dry matter intake (kg/day); ADG: Average daily gain (kg/day); TWG: Total weight gain (kg/animal); FC: Feed conversion ( $\mathrm{kg}$ of dry matter / kg of weight gain); PE: Protein efficiency ( $\mathrm{kg}$ of weight gain $/ \mathrm{kg}$ of crude protein). Means followed by different letters in the row differ according to Tukey's test $(\mathrm{p}<0.05)$. CV: Coefficient of variation.

Diets containing Jiggs hay provided higher DMI, ADG, and TWG and better FC for animals compared to the remaining diets. The smallest
DMI was observed in diets containing Tifton 68 hay. The marginal variation compared to Jiggs was $19.05 \%$. The better response of Jiggs hay 
regarding the lambs' performance can be explained by the chemical (Table 2) and morphophysiological characteristics of this genotype, such as a better leaf:stem ratio, better ruminal degradation of dry matter and fiber, and higher ruminal degradation rate, when considering the same age of regrowth between genotypes, as observed by Oliveira et al. (2014a, b).

However, the DMI of lambs observed in this study is close to that recommended by the NRC (2007), which is between 0.5 and $1.315 \mathrm{~kg} /$ day for lambs weighing $22 \mathrm{~kg}$, assuming moderate growth and finishing potentials. The greatest DMI of diets based on Jiggs hay was reflected in higher the ADG and TWG of animals, with values of $0.180 \mathrm{~kg} /$ day and $15.14 \mathrm{~kg}$, respectively. The opposite occurred with the animals that consumed the Coast cross hay, where the ADG and TWG were 27.77 and $27.47 \%$ lower than for the Jiggs hay. The other genotypes showed intermediate values. The analysis of the chemical composition of the Coast cross diet in Table 2 revealed higher cell wall (NDF) and lignin contents compared to the remaining diets. These chemical factors most likely affected the DMI and ADG. According to Van Soest (1994), forage with high levels of fiber and lignin can remain in the gastrointestinal tract longer, causing reduced voluntary intake and animal performance, a fact that corroborates the results observed in this study for the Coast crossbased diets. For feedlot Santa Inês lambs fed diets with $40 \%$ Tifton 85 hay (78\% NDF and $44.07 \%$ ADF), Gerassev et al. (2013) reported DMI, ADG and $\mathrm{FC}$ values of $0.877 \mathrm{~kg} / \mathrm{day}, 0.106 \mathrm{~kg} / \mathrm{animal} /$ day and $8.39 \mathrm{~kg} \mathrm{DM} / \mathrm{kg}$ weight gain, respectively. These results indicate that the factors inherent to the chemical compositions of the diets are extremely important in animal performance, in addition to factors inherent to the environment, breeds and general handling of the animals used. For example, in temperate grasslands (extensive system), Gallardo et al. (2011) observed an NDF content of $33.5 \%$ of DM of the pasture and an ADG for Suffolk lambs of $0.300 \mathrm{~kg} /$ day.

In the economic evaluation of the diets, feed conversion is an important parameter to be measured. In this study, the results for FC show that animals fed diets based on Coast cross hay consumed $0.95,0.93,0.72,1.11$ and $0.36 \mathrm{~kg}$ more dry matter $(\mathrm{p}<0.05)$ than the lambs fed with Jiggs, Vaquero, Tifton 85 Tifton 68 and Russell hay, respectively, to reach the same weight gain, which in practice can mean a higher cost of feeding the animals. This result can be explained mainly by the lower ADG of the animals because $\mathrm{FC}$ is given by the ratio between the DMI and the ADG.

There were significant differences between the diets in terms of costs of food and total expenditure (Table 5).

The animals fed diets with Jiggs hay had higher expenditure on forage (EF), concentrate (EC) and cost of the complete diet, which possibly reflects the larger DMI observed in animals fed this diet. Consequently, higher total expenditure on food (TEF), total expenditure on the feedlot production system (TE) and costs per kilogram of live weight (CLW) were also observed in animals fed Jiggs hay. The CLW of the diet with Coast cross hay was higher compared to the CLW of diets based on Vaquero, Tifton 85, Tifton 68 and Russell, but it did not differ statistically from Jiggs hay. 
Table 5. Costs of food and total expenditure for feedlot lambs fed different diets of hay from grasses of the genus Cynodon.

\begin{tabular}{lccccccc}
\hline \multirow{2}{*}{ Variables } & \multicolumn{7}{c}{ Diets } \\
\cline { 2 - 7 } & Coast & Jiggs & Vaquero & Tifton 85 & Tifton 68 & Russell & CV (\%) \\
\hline EC & $0.190 \mathrm{ab}$ & $0.227 \mathrm{a}$ & $0.193 \mathrm{ab}$ & $0.186 \mathrm{ab}$ & $0.183 \mathrm{~b}$ & $0.187 \mathrm{ab}$ & 10.99 \\
ER & $0.266 \mathrm{ab}$ & $0.318 \mathrm{a}$ & $0.270 \mathrm{ab}$ & $0.262 \mathrm{ab}$ & $0.257 \mathrm{~b}$ & $0.262 \mathrm{ab}$ & 10.97 \\
$\mathrm{CCD}$ & $0.456 \mathrm{ab}$ & $0.545 \mathrm{a}$ & $0.463 \mathrm{ab}$ & $0.449 \mathrm{ab}$ & $0.441 \mathrm{~b}$ & $0.450 \mathrm{ab}$ & 10.97 \\
TEF & $35.148 \mathrm{ab}$ & $48.962 \mathrm{a}$ & $35.499 \mathrm{ab}$ & $33.829 \mathrm{ab}$ & $32.028 \mathrm{~b}$ & $33.344 \mathrm{ab}$ & 21.54 \\
DE & $62.320 \mathrm{ab}$ & $76.136 \mathrm{a}$ & $62.670 \mathrm{ab}$ & $61.002 \mathrm{ab}$ & $59.198 \mathrm{~b}$ & $60.516 \mathrm{~b}$ & 12.34 \\
CLW & $3.115 \mathrm{a}$ & $3.238 \mathrm{a}$ & $2.754 \mathrm{ab}$ & $2.763 \mathrm{ab}$ & $2.544 \mathrm{~b}$ & $2.930 \mathrm{ab}$ & 9.62 \\
\hline
\end{tabular}

EC: Expenditure on concentrate (BRL/kg of NM) (Natural Matter); EF: Expenditure on forage (BRL/kg of FM); CCD: Cost of complete diet (BRL/kg of FM); TEF: Total expenditure on food (BRL); DE: Total expenditure (BRL/animal); CLW: Cost of kg of live weight (BRL). Means followed by different letters in the row differ according to Tukey's test ( $p<0.05)$. CV: Coefficient of Variation.

The diet based on Tifton 68 hay had lower costs compared to other diets, with marginal variations of 34.59 and $22.25 \%$ for TEF and TE, respectively, compared to Jiggs, which had higher costs. The variation in CLW between the diets ranged from BRL 2.54/kg to BRL $3.23 \mathrm{~kg}$, reflecting the variations in TEF and TE.

Gerassev et al. (2013), when evaluating the inclusion of $20 \%$ to $40 \%$ of banana leaf and pseudostem and $40 \%$ Tifton 85 hay in the diet of finishing lambs, observed variations of BRL 5.06/ $\mathrm{kg}$ to BRL 3.80/kg per live kilo produced, which are much higher values than the results found in this study. Azevedo et al. (2012) evaluated the addition of $0 \%$ to $30 \%$ macauba cake in the diet of feedlot lambs and observed variations ranging from BRL 2.19/kg to BRL $2.37 / \mathrm{kg}$ per live kilo produced, which are well below the values obtained in this study.

When the GR provided by the different diets was analyzed (Table 6), the sale of the slaughtered animals did not statistically change the GR, with an average of BRL 174.17/animal.

Table 6. Final live weight (FLW) and cold carcass weight (CCW) in $\mathrm{kg}$ and gross revenue (GR) and net revenue (NR) in BRL/animal for feedlot lambs receiving different diets of hay from grasses of the genus Cynodon.

\begin{tabular}{lccccccc}
\hline \multirow{2}{*}{ Variables } & \multicolumn{7}{c}{ Diets } \\
\cline { 2 - 7 } & Coast & Jiggs & Vaquero & Tifton 85 & Tifton 68 & Russell & CV (\%) \\
\hline FLW & $32.42 \mathrm{c}$ & $36.50 \mathrm{a}$ & $34.20 \mathrm{ab}$ & $33.42 \mathrm{ab}$ & $34.18 \mathrm{ab}$ & $33.11 \mathrm{ab}$ & 6.02 \\
$\mathrm{CCW}$ & 14.04 & 15.05 & 14.92 & 14.26 & 14.87 & 13.94 & 6.05 \\
\hline GR & 168.542 & 180.588 & 179.040 & 171.108 & 178.460 & 167.282 & 6.05 \\
NR & $106.220 \mathrm{c}$ & $104.456 \mathrm{c}$ & $116.370 \mathrm{ab}$ & $110.110 \mathrm{abc}$ & $119.262 \mathrm{a}$ & $106.768 \mathrm{ab}$ & 4.46 \\
\hline \multicolumn{7}{c}{ Sale of Live Animal } \\
\hline GR & $177.024 \mathrm{~b}$ & $199.294 \mathrm{a}$ & $186.758 \mathrm{ab}$ & $182.498 \mathrm{ab}$ & $186.624 \mathrm{ab}$ & $180.792 \mathrm{ab}$ & 7.02 \\
LR & $114.704 \mathrm{~b}$ & $123.158 \mathrm{ab}$ & $124.086 \mathrm{ab}$ & $121.502 \mathrm{ab}$ & $127.426 \mathrm{a}$ & $120.278 \mathrm{ab}$ & 4.37 \\
\hline
\end{tabular}

Means followed by different letters in the row differ according to Tukey's test $(\mathrm{p}<0.05)$. CV: Coefficient of variation. 
The results obtained are because the animals do not differ ( $p>0.05$ ) with respect to the $\mathrm{CCW}$, with an average of $14.51 \mathrm{~kg}$ /animal and a true carcass yield of 42.74\% (OLIVEIRA et al., 2014c). However, when the animals were sold alive, the GR was higher for animals fed diets based on Jiggs hay (BRL 199.24/animal) compared to the remaining diets. This fact can be explained by the higher final body weight of animals fed diets with Jiggs hay. However, the animals fed diets based on Tifton 68 hay had higher NR (BRL 127.42/animal) when sold alive and higher NR (BRL 119.26/ animal) when sold slaughtered compared to the other diets, which is possibly due to the direct relationship with lower TE (Table 5). However, the marginal variations of NR for animals sold slaughtered and alive were BRL 14.70/animal and BRL 12.72/animal, respectively. Thus, the confinement of 30 lambs under the experimental conditions adopted here, using diets based on Jiggs hay and then selling the animals slaughtered or alive, means that the producer would miss the opportunity to earn an additional BRL 441.00 and BRL 117.48, values that are significant for smaller properties, such as family farmers and large-scale producers.

Regarding the rates of return and the profitability of lambs, there were significant differences between diets, with higher rates and profitabilities in diets based on Tifton 68 (Table 7).

Table 7. Rate of return and profitability of feedlot lambs sold alive and/or slaughtered.

\begin{tabular}{lccccccc}
\hline \multirow{2}{*}{ Variables } & \multicolumn{7}{c}{ Diets } \\
\cline { 2 - 7 } & Coast & Jiggs & Vaquero & Tifton 85 & Tifton 68 & Russell & CV (\%) \\
\hline $\mathrm{RR}^{1}$ & $1.884 \mathrm{ab}$ & $1.634 \mathrm{~b}$ & $1.996 \mathrm{ab}$ & $2.036 \mathrm{ab}$ & $2.162 \mathrm{a}$ & $1.998 \mathrm{ab}$ & 11.00 \\
$\mathrm{RR}^{2}$ & $1.744 \mathrm{ab}$ & $1.386 \mathrm{~b}$ & $1.874 \mathrm{a}$ & $1.846 \mathrm{a}$ & $2.020 \mathrm{a}$ & $1.772 \mathrm{ab}$ & 11.43 \\
$\mathrm{P}^{1}$ & $22.512 \mathrm{~b}$ & $31.310 \mathrm{ab}$ & $31.980 \mathrm{a}$ & $29.224 \mathrm{ab}$ & $34.632 \mathrm{a}$ & $27.054 \mathrm{ab}$ & 16.01 \\
$\mathrm{P}^{2}$ & $14.028 \mathrm{~b}$ & $12.608 \mathrm{~b}$ & $24.264 \mathrm{a}$ & $17.832 \mathrm{ab}$ & $26.468 \mathrm{a}$ & $13.544 \mathrm{~b}$ & 24.22 \\
\hline
\end{tabular}

$\mathrm{RR}^{1}$ : Rate of return (sale of the live animal) (\%); $\mathrm{RR}^{2}$ : Rate of return (slaughtered animal); $\mathrm{P}^{1}$ : Profitability for live animal (\%); $\mathrm{P}^{2}$ : Profitability for slaughtered animal (\%). Means followed by different letters in the row differ according to Tukey's test ( $\mathrm{p}<0.05)$. $\mathrm{CV}$ : Coefficient of variation.

The animals fed diets based on Tifton 85 and Vaquero hays also showed higher rates of return when slaughtered $\left(\mathrm{RR}^{2}\right)$ and, hence, higher profitability $\left(\mathrm{L}^{2}\right)$ for the Vaquero hay. Lower return rates were observed for lambs fed diets based on Jiggs hay, most likely due to higher TEF because, even considering the higher ADG and FC compared to the other treatments, these results did not exceed production costs, thereby causing lower NR and lower RR ${ }^{2}$. However, the diets studied showed positive and satisfactory values for the rate of return and profitability. This result indicates that the activities cover the TEF and TE, which confirms the trend of financial gain, particularly for the treatment with Tifton 85 hay.

Gerassev et al. (2013), in evaluating the profitability of producing meat sheep in feedlots, reported that profitability varied from $54 \%$ to $71.95 \%$. Profitability varies according to several factors, mainly factors inherent to the acquisition costs of the ingredients that compose diets, which can reach $80 \%$ of total costs.

\section{Conclusion}

Grasses of the genus Cynodon dactylon used in this study have nutritional potential to be used in the diets of finishing lambs. 
The use of diets based on Tifton 68 hay for finishing lambs in feedlot allows for greater economic profitability compared with the remaining diets analyzed.

\section{Acknowledgements}

The authors thank the Federal University of Grande Dourados (Universidade Federal da Grande Dourados), the National Counsel of Technological and Scientific Development (Conselho Nacional de Desenvolvimento Científico e Tecnológico - CNPq) and the Brazilian Federal Agency for Support and Evaluation of Graduate Education (Coordenação de Aperfeiçoamento de Pessoal de Nível Superior CAPES) for the financial support and scholarships granted.

\section{References}

AZEVEDO, R. A.; RUFINO, L. M. A.; SANTOS, A. C. R.; SILVA, L. P.; BONFÁ, H. C.; DUARTE, E. R.; GERASEEV, L. C. Desempenho de cordeiros alimentados com inclusão de torta de macaúba na dieta. Pesquisa Agropecuária Brasileira, Brasília, v. 47, n. 11, p. 1663-1668, 2012.

CENTRO DE ESTUDOSAVANÇADOS EM ECONOMIAAPLICADA - CEPEA. PIB Cadeias Agropecuárias CEPEA-USP/CNA. Piracicaba: [s.n.], 2014. Disponível em: <http://www.cepea.esalq.usp.br>. Acesso em: 20 jun. 2014.

EMPRESA BRASILEIRA DE PESQUISA AGROPECUÁRIA - EMBRAPA. Centro Nacional de Pesquisa de Solos. Sistema brasileiro de classificação de solos. Brasília: Serviço de Produção de Informação, 1999. $412 \mathrm{p}$.

GAllardo, M. A.; PUlidO, R. P.; GAllo, C. Fatty acid composition of longissimus dorsi muscle of Suffolk down lambs fed on different dryland forages. Chilean journal of agricultural research, Valdivia, v. 71, n. 4, p. 566- 571, 2011.

GERASSEV, L. C.; MOREIRA, S. J. M.; ALVES, D. D.; AGUIAR, A. C. R.; MONÇÃO, F. P.; SANTOS, A. C. R.; SANTANA, C. J. L.; VIEGAS, C. R. Viabilidade econômica da utilização dos resíduos da bananicultura na alimentação de cordeiros confinados. Revista Brasileira de Saúde e Produção Animal, Salvador, v.
14, n. 4, p. 734-744, 2013.

KÖPPEN, W. Climatologia tradicional. Traduzido por Pedro Henchiehs Pérez. México: Fondo de Cultura Econômica, 1948. 479 p.

NATIONAL RESEARCH COUNCIL - NRC. Nutrient requeriments of small ruminants. $7^{\text {th }}$ ed. Washington, D.C.: National Academic Press, 2007. 362 p.

OLIVEIRA, E. R.; MONÇÃO, F. P.; GABRIEL, A. M.A.; GÓES, R. H. T. B.; LEMPP, B.; MOURA, L. V. Ruminal degradability of neutral detergent fiber of Cynodon spp. grasses at four regrowth ages. Acta Scientiarum. Animal Sciences, Maringá, v. 36, n. 2, p. 201-208, 2014b.

OLIVEIRA, E. R.; MONÇÃO, F. P.; GABRIEL, A. M. A.; MOURA, L. V.; LEMPP, B.; SANTOS, M. V.; RAYANNE SOUZA, R. Degradação ruminal da biomassa de fenos de gramíneas do género Cynodon spp. Revista de Ciências Agrárias, Lisboa, v. 37, v. 2, p. 104110, 2014a.

OLIVEIRA, E. R.; MONÇÃO, F. P.; HOSTALÁCIO, A. N.; SANTOS, M. V.; FERNANDES, A. R. M.; GABRIEL, A. M. A.; MORAIS, M. G.; MOURA, L. V. Características de carcaça e de carne de cordeiros alimentados com dietas contendo diferentes genótipos de Cynodon. Semina: Ciências Agrárias, Londrina, v. 35, n. 4, p. 2563-2578, 2014c. Suplemento.

PACHECO, P. S.; PASCOAL, L. L.; RESTLE, J.; VAZ, F. N.; ARBOITTE, M. Z.; VAZ, R. Z.; SANTOS, J. P. A.; OLIVEIRA, T. M. L. Risk assessment of finishing beef cattle in feedlot: slaughter weights and correlation amongst input variables. Revista Brasileira de Zootecnia, Viçosa, MG, v. 43, n. 2, p. 92-99, 2014 b.

PACHECO, P. S.; SILVA, R. M.; PADUA, J. T.; RESTLE, J.; TAVEIRA, R. Z.; VAZ, F. N.; PASCOAL, L. L.; OLEGARIO, J. L.; MENEZES, F. R. Análise econômica da terminação de novilhos em confinamento recebendo diferentes proporções de cana-de-açúcar e concentrado. Semina: Ciências Agrárias, Londrina, v. 35, n. 2, p. 999 1012, 2014a.

PATTERSON, T.; KLOPFENSTEIN, T. J.; MILTON, T.; BRINK, D. R. Evaluation of the 1996 beef cattle NRC model predictions of intake and gain for calves fed low or medium energy density diets. Nebraska Beef Report, v. 1, n. 1, p. 26-29, 2000.

PUPO, N. I. H. Manual de pastagens e forrageiras: formação, conservação e utilização. Campinas: Instituto Campineiro de Ensino Agrícola, 1979. 343 p.

STATISTICAL ANALYSIS SYSTEM INSTITUTE SAS. SAS INSTITUTE. SAS Systems for windows: Version 9. 2. Cary, 2008. 
SCOTCONSULTORIA-Boi \& Companhia. Informativo Pecuário Semanal 1082. Cidade Piracicaba: Editora, 2014. Disponível em: < https://www.scotconsultoria. com.br/loja/informativos/38/boi-\&-companhia(informativo-pecuario-semanal) $>$. Acesso em: 20 jun. 2014.
SOUZA, A.; CLEMENTE, A. Decisões financeiras $e$ análise de investimentos. 6. ed. São Paulo: Atlas, 2009. $186 \mathrm{p}$.

VAN SOEST, P. J. Nutritional ecology of the ruminant. $2^{\text {th }}$ ed. Ithaca: Cornel University Press, 1994. 476 p. 